\title{
Assessment of the Effectiveness of Post Graduate Diploma in Education (PGDE) Programme in Meeting the Job Needs of Teachers in Gboko, Benue State, Nigeria
}

\author{
Emmanuel Okechukwu Chukwu ${ }^{1}$, Iormough Jonah Tarnongu ${ }^{2}$, Fiase Terna Mesuur ${ }^{1}$, \\ Achukwu Chinyere Evangeline ${ }^{1}$, Chia Terkuma ${ }^{3}$ \\ ${ }^{1}$ School of Nursing Mkar, Gboko, Nigeria \\ ${ }^{2}$ School of Nursing Makurdi, Makurdi, Nigeria \\ ${ }^{3}$ Department of Anatomy, University of Nigeria, Enugu, Nigeria
}

Email address:

emmanwaguy42@yahoo.com (E. O.Chukwu)

\section{To cite this article:}

Emmanuel Okechukwu Chukwu, Iormough Jonah Tarnongu, Fiase Terna Mesuur, Achukwu Chinyere Evangeline, Chia Terkuma. Assessment of the Effectiveness of Post Graduate Diploma in Education (PGDE) Programme in Meeting the Job Needs of Teachers in Gboko, Benue State, Nigeria. International Journal of Education, Culture and Society. Vol. 2, No. 2, 2017, pp. 69-75.

doi: $10.11648 /$ j.ijecs.20170202.14

Received: February 23, 2017; Accepted: March 11, 2017; Published: March 28, 2017

\begin{abstract}
This study was designed with an objective to assess the effectiveness of the PGDE programme in meeting the job needs of teachers in secondary schools in Gboko local government area of Benue state. A cross sectional descriptive survey design was used in the study. The instrument used for the data collection is a well-structured questionnaire consisting of 26 questionnaire items. 320 respondents were sampled from sixteen schools in Gboko using the purposive and stratified sampling techniques. The results obtained were analyzed using mean, standard deviation and variance. Findings revealed that secondary school teachers in Gboko were mainly HND holders (39\%). The findings also showed that majority of the respondents were aware of the PGDE programme (both holders and non-holders of the PGDE certificate). Furthermore, the study indicated that PGDE holders were more proficient in the utilisation of teaching aids. All four hypotheses were tested and the researcher observed that there was no significant difference in knowledge of the PGDE programme among teachers who were PGDE holders and those without the certificate. The researcher noted a significant difference in the effectiveness of PGDE holders and non-holders in terms of their methodological competencies. The researcher further discovered that there existed a significant difference in the level of utilisation of teaching aids between PGDE holders and non-holders. It also revealed clearly that students understood lessons better when taught by PGDE holders than when taught by those without the certificate. The study then recommended among others that employment of teaching staff should be anchored on technical expertise while teachers without the PGDE certificate should be encouraged to acquire the certificate through sponsorship.
\end{abstract}

Keywords: Assessment, Effectiveness, PGDE, Programme, Job, Needs, Teachers

\section{Introduction}

Quality of teachers is important in any meaningful presentation of educational transactions. The concept of education cannot be properly defined or conceptualized without reference to those who impact the knowledge (Double Gist, 2013). The National Policy on Education (2004) views education as an instrument par excellence for effecting national development. An educational system is effective to the extent it makes use of the available resources to achieve its stated aims and objectives. The major objective of every school system irrespective of the level of education is to provide high quality education for learners (Whawo, 1993). In addition, the success of any educational system no doubt depends on the available methodological competence, educational qualification level, and the administrative machinery established for its implementation. In recognition of this fact, therefore, professionalism is given a major emphasis in all teaching 
activities. For this reason, there has been an upsurge in attempts to acquire professional teaching qualifications such as the Nigeria Certificate in Education (NCE), Bachelor of Arts Education (B. A. Ed), Bachelor of Science Education (B. Sc. Ed), Bachelor of Education (B. Ed.), Master of Education (M. Ed.), Doctor of Philosophy (Ph. D.) in education, and other educational qualifications that are needed to become a professional teacher in Nigeria (Ololube, 1997), such as the PGDE programme.

The Philosophy of PGDE Programme is to produce educators who will serve as agents of positive change through the social engineering processes of education as teachers, researchers, experts, educational policy/programme designers, developers, implementers, evaluators and experts whose services shall be useful in related fields of national and international development (TRCN, 2010).

According to Premium Times (2016) over 60 percent of teachers in public primary and secondary scools in the northern Nigeria (Benue State being inclusive) are unqualified. This is true of the statement by the former Acting Permanent Secretary, Federal Ministry of Education, Hajia Hindatu Abdullahi that "many Nigerian teachers are not qualified, hence has no requisite skills and capacity to impact knowledge, a factor responsible for mass examination failures in recent times" ( MetroNaija, 2015; GistMania, 2010). “About 80 percent of all school teachers in most states in the north were not qualified for the job", according to the Director General of National Institute of Teachers, Dr. Aminu Sharehu (Luka, 2013).

In Nigeria, reasonable preparations are made to improve teachers' professional development through the establishment of colleges of education, both at the federal and state levels. Institutes of education and faculties of education in various universities are also established to provide effective and professional teacher education programs. In such institutions, students are trained to form habits that will help them become teachers capable of shouldering responsibilities, showing initiative and being good models for their future pupils. An incompetent teacher is a disgrace to the teaching profession. Such incompetence may be a matter of low intellectual capacity, inadequate training, and resistance to modern pedagogical methods, or poor attitude about the teaching profession and a lack of dedication to professional duties.

The PGDE Programme is theoretical and practical. It includes important aspects of teaching and learning. The programme addresses the philosophical problems of the bases of educational practice, the diverse human settings within which teaching and learning occur, the practical process and content of teaching, the definition of the teacher's role and teaching ethics. At the end of the programme, learners should have in-depth knowledge of education and the professional requirements as well as competence to adequately teach at various levels of education and function effectively in other organisations. In Nigeria this is again evident by our corps members who are sent to teach with little or no professional teaching qualification. This conception is not good for the profession. There has been a general conception in Nigeria among teaching and nonteaching staff that the ability to teach with enthusiasm may be both in-born and acquired. It was further argued in Ololube's discussion and evaluation with university colleagues that academic qualification without undergoing a period of professional training is all that is required for teaching competence. In this paradigm, the public see intelligence, interest, and other personal traits as the only qualities assumed to be necessary for effective teaching. Therefore, they concluded that teacher education is unworthy. The need for the PGDE programme however, cannot be over emphasized. The researchers wishes to debunk the assertion that the PGDE programme is useless. It is against this backdrop that the researchers sets out to assess the effectiveness of the PGDE programme in meeting the job needs of teachers in secondary schools in Gboko Local Government Area of Benue state.

\subsection{Objectives of the Study}

The overall objective of the study is to ascertain the effectiveness of the Post Graduate Diploma in Education (PGDE) programme to teachers. The specific objectives of the study include:

1. To assess teachers' level of understanding of the PGDE programme.

2. To investigate the methodological competencies of PGDE holders as teachers.

3. To examine the ability of those who have undergone the PGDE programme to utilize teaching aids.

4. To ascertain the extent to which the PGDE programme assists students' understanding of lessons.

\subsection{Research Hypotheses}

1. There is no significant difference in knowledge of the PGDE programme among teachers who are holders of the PGDE certificate and those without it.

2. There is no significant difference in the effectiveness of PGDE holders and non-professional teachers in terms of their methodological competencies.

3. There is no significant difference in the level of utilization of teaching aids between PGDE holders and non-holders.

4. There is no significant difference in understanding among students when receiving lectures from teachers who are holders of PGDE and teachers without the certificate.

\section{Research Methodology}

\subsection{Research Design}

Cross sectional descriptive survey design was the research design used to assess the effectiveness of the PGDE programme in meeting the job needs of teachers in secondary schools in Gboko LGA of Benue state. 


\subsection{Study Population}

The population of the study was made up of all secondary school teachers in Gboko in both private and government owned schools. This involved all teachers of secondary schools in Gboko, the ratio of teachers with PGDE to non PGDE holders in these schools being 580:911 (Area Education Office, Gboko). This gave a total of 1491 teachers.

\subsection{Sample Size}

This was made up of $21.4 \%$ of the total population. This is in accordance with Nwana (2008), who stated that "for a population of simple thousands (1000-9000), ten percent and above of the total population could be selected and used as the sample." Thus, for this population, a sample size of 128 PGDE holders (22\% of 580) and 192 non PGDE holders ( $21 \%$ of 911 ) was used. This approximated to a total of 320 participants.

\subsection{Sampling Technique}

A multi staged cluster and stratified sampling techniques were adopted for the study. Gboko was divided into Gboko East, West, North and South. Four schools were then selected from each of these areas using paper balloting to arrive at two private and two grant-aided schools. This gave a total of sixteen schools. The second stage involved selection of teachers for the exercise. The teachers were grouped into two; PGDE holders and non PGDE holders. Using the stratified sampling technique, eight (8) PGDE holders and twelve (12) non PGDE holders were selected from each school. This gave a total of 128 PGDE holders and 192 non PGDE holders and a total of 320 respondents.

\subsection{Instrument for Data Collection}

The research instrument used by the researcher was a questionnaire made up mainly of 30 structured questions and a few open-ended questions. The questionnaire consisted of the following sections: Section A: Socio-demographic variables; Section $B$ : Understanding of the PGDE programme; Section C: Teachers' methodological competencies; Section D: Teachers ability to utilise teaching aids/ materials; Section E: Extent to which PGDE programme assist students' understanding of lessons.

\subsection{Method of Data Collection}

The researcher collected data through the distribution of questionnaire to the 320 sampled teachers in the selected secondary schools. The researcher employed the services of two (2) trained research assistants in the distribution of the questionnaire. The questionnaires were self-administered by participants and all were retrieved.

\subsection{Method of Data Analysis}

The data was analyzed by the use of simple statistical measures such as frequency distribution tables and percentages. Hypotheses were tested using mean, standard deviation and variance.

\section{Data Presentation and Discussion}

\subsection{Demographic Characteristics of the Respondents}

Table 1. Socio-Demographic characteristics of respondents.

\begin{tabular}{|c|c|c|c|}
\hline Characteristics & & Frequency & Percentage \\
\hline \multirow[t]{6}{*}{ Age } & $20-25$ & 42 & 13.1 \\
\hline & $26-30$ & 63 & 19.7 \\
\hline & $31-35$ & 95 & 29.7 \\
\hline & $36-44$ & 100 & 31.3 \\
\hline & 45 and above & 20 & 6.2 \\
\hline & Total & 320 & 100 \\
\hline \multirow[t]{3}{*}{ Sex } & Male & 215 & 67.2 \\
\hline & Female & 105 & 32.8 \\
\hline & Total & 320 & 100 \\
\hline \multirow[t]{4}{*}{ Marital status } & Single & 143 & 44.7 \\
\hline & Married & 135 & 42.2 \\
\hline & Divorced & 42 & 13.1 \\
\hline & Total & 320 & 100 \\
\hline \multirow[t]{3}{*}{ Religion } & Christianity & 304 & 95 \\
\hline & Islam & 16 & 5 \\
\hline & Total & 320 & 100 \\
\hline \multirow[t]{9}{*}{$\begin{array}{l}\text { Highest academic } \\
\text { qualification }\end{array}$} & ND & 12 & 3.8 \\
\hline & NCE & 42 & 13.1 \\
\hline & HND & 125 & 39 \\
\hline & Bachelor degree & 51 & 15.9 \\
\hline & PGDE & 62 & 19.4 \\
\hline & Masters & 21 & 6.6 \\
\hline & Ph. D & 7 & 2.2 \\
\hline & Others & Nil & 0 \\
\hline & Total & 320 & 100 \\
\hline \multirow[t]{6}{*}{ Years in practice } & Less than 5years & 103 & 32.2 \\
\hline & $5-10$ years & 67 & 20.9 \\
\hline & $11-15$ years & 35 & 10.9 \\
\hline & $15-30$ years & 99 & 30.9 \\
\hline & More than 30 years & 16 & 5 \\
\hline & Total & 320 & 100 \\
\hline
\end{tabular}

The above table showed that $100(31.3 \%)$ respondents were within the age range of 36-44 representing majority of the respondents. Teachers above 45 years constituted the least number of respondents; 20, representing $6.2 \%$ of the respondents. Majority of the respondents (215) representing $67.2 \%$ of the sampled population were males. Females were 105 in number representing $32.8 \%$. Of the 320 respondents, $143(44.7 \%)$ were single while $135(42.2 \%)$ were married. The remaining 42 representing $13.1 \%$ were divorced. Christianity was the dominant religion of the study population with 304 (95\%) being Christians and a minority of 16 , being $5 \%$ of respondents were Muslims. The findings of the study reveal that secondary school teachers in Gboko were dominated by HND holders with a total of $125(39 \%)$, PGDE holders were $62(19.4 \%)$ while ND and NCE represented $3.8 \%$ (12) and $13.1 \%$ (42) respectively. The study further revealed that there were $21(6.6 \%)$ Masters 
degree holders and $7(2.2 \%)$ had doctorate degrees. In terms of years of practice, majority of the respondents, 103 (32.2\%) had less than five years teaching experience while those with more than 30 years experience were the least respondents, 16 , representing $5 \%$.

\subsection{Teachers' Level of Understanding of the PGDE Programme}

Table 2. Responses on understanding of the PGDE programme.

\begin{tabular}{lllll}
\hline \multirow{2}{*}{ Items } & \multicolumn{2}{l}{ PGDE holders } & \multicolumn{2}{l}{ Non PGDE holders } \\
\cline { 2 - 5 } & Mean & SD & Mean & SD \\
\hline 10 & 3.98 & 0.55 & 3.90 & 0.56 \\
11 & 3.94 & 0.56 & 3.87 & 0.57 \\
12 & 3.74 & 0.57 & 3.88 & 0.54 \\
13 & 3.98 & 0.55 & 3.95 & 0.53 \\
Total & 3.91 & 0.56 & 3.90 & 0.55 \\
\hline
\end{tabular}

The result as presented in the above table showed that majority of the respondents (both holders and non-holders of the PGDE certificate) were aware of the PGDE programme. This is in accord with the findings of Barker and Mehmood (2009); Owens (2004) that teachers who do not go for professional training are aware of the importance and agreed that such training is important.

\subsection{Utilization of Teaching Aids by Teachers}

Table 4. Responses on the level of utilisation of teaching aids by holders and non holders of the PGDE certificate.

\begin{tabular}{llllll}
\hline \multirow{2}{*}{ Competencies (variables) } & \multicolumn{2}{l}{ Teachers who are PGDE holders } & \multicolumn{2}{c}{ Non PGDE holders } \\
\cline { 2 - 6 } & Mean & SD & Variance & Mean & SD \\
\hline 17 & 3.74 & 0.44 & 0.19 & 1.90 & 0.82 \\
18 & 3.67 & 0.51 & 0.26 & 1.96 & 0.74 \\
19 & 3.64 & 0.49 & 0.24 & 2.33 & 0.80 \\
Total & 3.68 & 0.48 & 0.23 & 2.06 & 0.79 \\
\hline
\end{tabular}

The result showed a higher cumulative mean for the PGDE holders which was an indication of the fact that PGDE holders were more competent in terms of ability to make use of teaching aids than their counterparts. This finding is supported by Killion and Joellen (2013) Kane and Staiger (2012) that teachers educational training is the panacea for quality teaching and learning.

\subsection{Students' Understanding of Lessons in Class}

Table 5. Responses on student understanding of lessons in class.

\begin{tabular}{lllllll}
\hline \multirow{2}{*}{$\begin{array}{l}\text { Competencies } \\
\text { (Variables) }\end{array}$} & \multicolumn{3}{l}{$\begin{array}{l}\text { Teachers who are PGDE } \\
\text { holders }\end{array}$} & \multicolumn{4}{l}{$\begin{array}{l}\text { Teachers who are non } \\
\text { PGDE holders }\end{array}$} \\
\cline { 2 - 7 } & Mean & SD & Variance & Mean & SD & Variance \\
\hline 20 & 3.72 & 0.59 & 0.34 & 1.71 & 0.53 & 0.28 \\
21 & 3.67 & 0.53 & 0.28 & 1.66 & 0.52 & 0.27 \\
22 & 3.55 & 0.57 & 0.32 & 1.83 & 0.56 & 0.31 \\
23 & 3.71 & 0.65 & 0.42 & 1.77 & 0.53 & 0.28 \\
24 & 3.78 & 0.58 & 0.33 & 1.74 & 0.54 & 0.29 \\
25 & 3.75 & 0.59 & 0.34 & 1.71 & 0.53 & 0.28 \\
26 & 3.52 & 0.65 & 0.42 & 1.78 & 0.56 & 0.31 \\
Total & 3.67 & 0.59 & 0.35 & 1.74 & 0.53 & 0.28 \\
\hline
\end{tabular}

The study clearly indicated that PGDE holders taught

\subsection{Methodological Competence of Teachers}

Table 3. Responses on methodological competence of teachers.

\begin{tabular}{lllllll}
\hline \multirow{2}{*}{$\begin{array}{l}\text { Competencies } \\
\text { (variables) }\end{array}$} & \multicolumn{3}{l}{$\begin{array}{l}\text { Teachers who are } \\
\text { PGDE holders }\end{array}$} & \multicolumn{3}{l}{ Non PGDE holders } \\
\cline { 2 - 7 } & Mean & SD & Variance & Mean & SD & Variance \\
\hline 14 & 3.65 & 0.54 & 0.29 & 2.07 & 0.85 & 0.72 \\
15 & 3.56 & 0.56 & 0.31 & 1.75 & 0.75 & 0.56 \\
16 & 3.47 & 0.73 & 0.53 & 1.84 & 0.73 & 0.53 \\
Total & 3.56 & 0.61 & 0.37 & 1.89 & 0.78 & 0.60 \\
\hline
\end{tabular}

The result showed that teachers with PGDE certificate consistently scored higher than those without the certificate in terms of their methodological competences. This visible impression was an indication that distinguished the professional teachers from the non-professional teachers in the area of teaching competencies. This lended support to the education effectiveness researchers (Allison, 2013; Vanderburg and Stephens, 2010; Scheerens, 2000) that professional training of teachers should not be undermined.

That is, teachers ought to be professionally competent before they can be called expert in their job. This study observed that non PGDE holders (academically qualified teachers) were unskilled and as such not competent to carry out effective instructional processes. The incompetent teacher does not know how to effectively utilize the vast teaching methods available during classroom lessons. Thus, they were 'skilled incompetent'.

better and were well understood by students than teachers without the certificate. Through knowledge gained from the PGDE programme, holders were able to apply contemporary knowledge effectively, adopted proper questioning skills during lessons, utilised proper curricula and clearly stated their objectives in their lesson plan. The finding is in line with that of Youngs, (2013), Butler and Schnellert (2012) whose studies showed that teachers with better qualifications and training tends to do better in their professional carrier.

\subsection{Hypothesis 1: There Is no Significant Difference in Knowledge of the PGDE Programme Among Holders of the PGDE Certificate and Those Without it}

Table 6. Mean and standard deviation of differences in level of understanding of the PGDE programme between holders and non-holders of the PGDE certificate.

\begin{tabular}{lllll}
\hline \multirow{2}{*}{ Items } & \multicolumn{2}{l}{ PGDE holders } & \multicolumn{2}{l}{ Non PGDE holders } \\
\cline { 2 - 5 } & Mean & SD & Mean & SD \\
\hline 10 & 3.98 & 0.55 & 3.90 & 0.56 \\
11 & 3.94 & 0.56 & 3.87 & 0.57 \\
12 & 3.74 & 0.57 & 3.88 & 0.54 \\
13 & 3.98 & 0.55 & 3.95 & 0.53 \\
Total & 3.91 & 0.56 & 3.90 & 0.55 \\
\hline
\end{tabular}


The above table showed that although both mean and standard deviations for the PGDE holders (mean=3.91, SD= 0.56) were higher than those of non PGDE holders (mean=3.90, $\mathrm{SD}=0.55)$, the differences in these values were not much indicating that the null hypothesis stands; "There is no significant difference in knowledge of the PGDE programme among teachers who are holders of the PGDE certificate and those without it."

\subsection{Hypothesis 2: There Is no Significant Difference in the Effectiveness of PGDE Holders and Non-PGDE Holders Towards Their Methodological Competencies}

Table 7. Means and standard deviations of differences between PGDE holders and non-holders of the PGDE certificate towards their methodological competencies.

\begin{tabular}{lllll}
\hline \multirow{2}{*}{$\begin{array}{l}\text { Competencies } \\
\text { (variables) }\end{array}$} & $\begin{array}{l}\text { Teachers who are } \\
\text { PGDE holders }\end{array}$ & \multicolumn{2}{l}{ Non PGDE holders } \\
\cline { 2 - 5 } & Mean & $\begin{array}{l}\text { Standard } \\
\text { deviation (SD) }\end{array}$ & Mean & $\begin{array}{l}\text { Standard } \\
\text { deviation (SD) }\end{array}$ \\
\hline 14 & 3.65 & 0.54 & 2.07 & 0.85 \\
15 & 3.56 & 0.56 & 1.75 & 0.75 \\
16 & 3.47 & 0.73 & 1.84 & 0.73 \\
Total & 3.56 & 0.61 & 1.89 & 0.78 \\
\hline
\end{tabular}

The table above revealed that the cumulative mean and standard deviation scores for the PGDE holders $(M=3.56$, $S D=0.61)$ were higher than those of the non PGDE holders $(M=1.89, S D=0.78)$. This showed that there was a significant difference in the effectiveness of PGDE holders and non PGDE holders in the area of methodological competencies. The findings likewise revealed practical evidences that professional teachers tended to apply correct teaching methods in the teaching and learning process. This lended sufficient support to Teemant, Wink and Tyra (2011), that current work practices in the education industry were characterized by a strong emphasis on comparative work in small multidisciplinary teams.

At the same time, special knowledge or "professional competence" becomes obsolete more rapidly and the ability to acquire the skills relevant for teaching "just in time" grows in importance. Therefore, social and methodological competences gain importance just as professional competences. Obviously, those competences cannot be learned individually in lectures or traditional seminars, but require "teaching practice" and being engaged in a realworld context. This problem is addressed by offering educational projects to student teachers with a didactic concept that focuses on authentic teaching practice (Ololube, 2006).

From the preceding discussion, the findings have shown that there were multifaceted roles that teachers played in effecting quality in teaching. The information contained in the data showed that there were differences in the way PGDE holders and non PGDE holders go about their roles in the instructional process. Also, it was suggested that much importance should be attached to developing untrained teachers in the process of teacher training because quality teaching scored high in the evaluation of an effective teacher. This lended support to the works of Allison (2013); Vanderburg and Stephens, (2010); Ololube (2006); and Scheerens, 2000).

\subsection{Hypothesis 3: There Is no Significant Difference in the Effectiveness of PGDE Holders and Non-PGDE Holders Towards Their Utilization of Teaching Aids}

Table 8. Means and standard deviations of differences between PGDE holders and non-non holders towards their material utilization competencies.

\begin{tabular}{lllll}
\hline \multirow{2}{*}{$\begin{array}{l}\text { Competencies } \\
\text { (variables) }\end{array}$} & $\begin{array}{l}\text { Teachers who are } \\
\text { PGDE holders }\end{array}$ & \multicolumn{2}{l}{ Non PGDE holders } \\
\cline { 2 - 5 } & Mean & $\begin{array}{l}\text { Standard } \\
\text { deviation(SD) }\end{array}$ & Mean & $\begin{array}{l}\text { Standard } \\
\text { deviation (SD) }\end{array}$ \\
\hline 17 & 3.74 & 0.44 & 1.90 & 0.82 \\
18 & 3.67 & 0.51 & 1.96 & 0.74 \\
19 & 3.64 & 0.49 & 2.33 & 0.80 \\
Total & 3.68 & 0.48 & 2.06 & 0.79 \\
\hline
\end{tabular}

The result of the means and standard deviations between PGDE holders and non PGDE holders indicated that a variety of techniques were needed for teachers to effectively utilize instructional materials in the teaching and learning process. Therefore, this hypothesis was rejected, and the alternative hypothesis was upheld; "There is a significant difference in the level of utilization of teaching aids between PGDE holders and non PGDE holders."

In support of the result in "hypothesis three", Killion and Joellen (2013) Kane and Staiger (2012) Ololube (2006), and Austin, Dwyer and Freebody (2003) indicated that teachers who are professionally trained demonstrated a sound understanding of classroom technology operations and concepts and used productivity tools to enhance professional tasks such as correspondence, students' assessment, classroom materials and lesson presentations. Thus, teachers need to demonstrate introductory knowledge, skills, and understanding of concepts related to the use of materials needed for instructional process and the continual growth in technology, knowledge and skills to stay abreast of current and emerging technologies that support student learning and informed decisions regarding the use of technology in support of student learning. To give credence to these findings, according to Parkside (as cited in Ololube, 2010), a course like 'educational technology' was designed to equip student teacher candidates with the knowledge and skills necessary to use technology in the field of education. It was established to maintain rigorous standards for teacher candidates' knowledge and performance and to ensure that all students' teachers achieved the predetermined aims and objectives of education. Working from a solid content background, professional teachers demonstrated proficient and flexible use of different ways of teaching that actively engaged all students in learning. 


\subsection{Hypothesis 4: There Is no Significant Difference in Students' Understanding of Lessons From Teachers Who Are Holders of PGDE and Those Without PGDE}

Table 9. The means and standard deviations showing differences in level of lesson understanding by students between PGDE holders and non-holders.

\begin{tabular}{lllll}
\hline $\begin{array}{l}\text { Competencies } \\
\text { Variables) }\end{array}$ & \multicolumn{2}{l}{$\begin{array}{l}\text { Teachers who are PGDE } \\
\text { holders }\end{array}$} & \multicolumn{2}{l}{$\begin{array}{l}\text { Teachers who are non } \\
\text { PGDE holders }\end{array}$} \\
\hline & Mean & SD & Mean & SD \\
20 & 3.72 & 0.59 & 1.71 & 0.53 \\
21 & 3.67 & 0.53 & 1.66 & 0.52 \\
22 & 3.55 & 0.57 & 1.83 & 0.56 \\
23 & 3.71 & 0.65 & 1.77 & 0.53 \\
24 & 3.78 & 0.58 & 1.74 & 0.54 \\
25 & 3.75 & 0.59 & 1.71 & 0.53 \\
26 & 3.52 & 0.65 & 1.78 & 0.56 \\
Total & 3.67 & 0.59 & 1.74 & 0.53 \\
\hline
\end{tabular}

The results from table 9 indicated that both the mean and standard deviations for PGDE holders (mean=3.67 and $\mathrm{SD}=$ 0.59) were higher than those of non PGDE holders. This implied that a significant difference existed in the level of understanding among students when attending lessons from PGDE holders and non PGDE holders. This was indicative of the fact that PGDE holders applied contemporary knowledge and ideas to their job, made proper use of questioning skills, developed proper course curricula and were efficient in time management. The result further showed that PGDE holders showed sufficient mastery of subject matter, were good at classroom management, in developing their lesson plan and they clearly stated their objectives. Youngs, (2013), Butler and Schnellert (2012) whose studies showed that teachers with better qualifications and training tends to do better in their professional carrier.

\section{Limitations of the Study}

The limitation has to do with the number of schools that could be included in the study and the generalizability of the findings. Although the researchers attempted to improve the generalizability of the results by inferring from a multiple of sixteen schools, it would be difficult to conclude from only sixteen schools out of the many schools in Gboko. This study uses the opinions of teachers in sixteen selected secondary schools in Gboko. This may not represent the opinions of other teachers in other parts of Benue state. As this is the case, it will be inappropriate for one to assume that their opinions represent those of other teachers. However, following the principles of interpretation research, generalization is not sought from the setting of a population, rather it supplies an understanding of the deeper structure of a phenomenon that can inform other settings.

\section{Conclusion}

The overall objective of this study as earlier stated was to assess the effectiveness of PGDE programme in meeting the job needs of teachers in secondary schools in Gboko local government area of Benue state. The findings showed that no significant difference existed in level of awareness about the PGDE programme between the holders and non holders of the PGDE. In terms of their methodological competence, the null hypothesis was rejected as the findings revealed that significant difference existed in the methodological competence between the PGDE holders and non PGDE holders. On grounds that the PGDE holders exhibited proficiency in the utilization of teaching aids more than the non PGDE holders, the third null hypothesis was rejected. The researchers again saw that there existed a significant difference in level of understanding among students when taught by PGDE holders and the non PGDE holders. The mean and standard deviations for the PGDE holders were in divergence of the mean and standard deviation for the non PGDE holders indicating that the PGDE holders were more competent in the art and science of teaching.

\section{References}

[1] Allison G. (2013) The Teachers Effective Professional Development in an Era of High Stakes Accountability. Centre for Public Education. Retrieved from: www. centreforpubliceducation. org.

[2] Austin, H., Dwyer, B. and Freebody, P. (2003) Schooling the Child: The Making of Students in Classrooms. London: Falmer.

[3] Barker E. and Mehmood, K. (2009) Workshop: Effects of Teachers Training \& Pakistani Needs of Future. Teachers and Trainers in Adult Education and Lifelong learning. Professional Development in Asia \& Europe 29-30 June 2009 in Bergisch Glad Bach /Germany. p. 8.

[4] Butler, D. L. and Schnellert, L. (2012) Collaborative Inquiry in Teacher Professional Development. Teaching and Teacher Education, 28 (2012), 1206-1220.

[5] DoubleGist (2013) Academic Performance- The Effect of Shortage of Qualified Teachers on the Students. Retrieved from: www.doublegist.com/academic-performance-effectshortage-qualified-teachers-students/.

[6] GistMania (2010) Over 50 Percent Nigerian Teachers are not Qualified-FG. Retreived from: www. gistmania. com/talk/topic, 38622. 0. html.

[7] Kane, T. J. \& Staiger, D. O. (2012). Gathering Feedback for Teaching: Combining High-Quality Observations with Student Surveys and Achievement Gains. Seattle, WA: Bill and Melinda Gates Foundation.

[8] Killion, Joellen (2013). Establishing Time for Professional Development. Oxford, OH. Learning Forward.

[9] Luka, B. (2013) 80 Percent of Teachers in North UnqualifiedNTI. Retrieved from: www.vanguardngr.com/2013/07/80-ofteachers-in-north-unqualified-nti/.

[10] MetroNaija (2015) Many Nigerian Teachers are not Qualified. Retrieved from: www. metronaija. com/2015/10/manynigerian-teachers-are-not. html.

[11] National Policy on Education (2004) Federal Republic of Nigeria. $4^{\text {th }}$ Edition. 
[12] Nwana, O. C. (2008) Introduction to Educational Research. Ibadan. Heinemann Publisher.

[13] Ololube, N. P. (1997). An Appraisal of Teachers' Perception of Academic and Professional Training on Teachers' Job Effectiveness in Secondary Schools in Ndokwa East local Government Area of Delta state of Nigeria. Unpublished Masters' degree thesis, (M. Ed). Delta State University Abraka, Nigeria.

[14] Ololube, N. P. (2006). Teacher Education, School Effectiveness and Improvement; A Study of Academic and Professional Qualification on Teachers' Job Effectiveness in Nigerian Secondary Schools. Unpublished dissertation. University of Helsinki.

[15] Owens, R. G. (2004). Organizational Behavior in Education: Adaptive Leadership and School Reform, ( $8^{\text {th }}$ Ed.). Boston: Pearson Education.

[16] Premium Times (2016) Nigeria: Over Half of Teachers in Sokoto Not Qualified. Retrieved from: www. allafrica. com/stories/201611010035. html.
[17] Scheerens, J. (2000). Fundamentals of Educational Planning: Improving School Effectiveness. Paris: UNESCO.

[18] Teemant, A., Wink, J., \& Tyra, S. (2011). Effects of coaching on teacher use of sociocultural instructional practices. Teaching and Teacher Education, 27 (2011), 683-693.

[19] TRCN. (2010). National benchmark for Post-graduate diploma in Education in Nigeria. Retrieved from PGDE\%20approved\%20by\%20Edu\%20Cmtee.pdfo.

[20] Vanderburg, M. and Stephens, D. (2010). The Impact of Literacy Coaches: What Teachers Value and How Teachers Change. The Elementary School Journal, 111 (1), 141-163.

[21] Whawo, D. D. (1993). Educational Administration, Planning and Supervision. Benin- City: Jodah publications.

[22] Youngs, P. (2013). Using Teacher Evaluation Reform and Professional Development to Support Common Core Assessments. Washington, D. C.: Center for American Progress. 